Canadian Journal of Higher Education Revue canadienne d'enseignement supérieur

Volume 46, No. 2, 2016, pages 181 - 205

\title{
Examining Undergraduate Students' Conceptions of Inquiry in Terms of Epistemic Belief Differences
}

Dawit Asrat Getahun

Bahir Dar University

Alenoush Saroyan

McGill University

Mark W. Aulls

McGill University

\begin{abstract}
The purpose of the study was to examine undergraduate students' conceptions of inquiry and the relationship of inquiry conceptions to epistemic beliefs. Data were obtained from 107 university students (80 female, 27 male) using an open-ended questionnaire to examine their conceptions of inquiry and Schommer's Epistemological Beliefs Questionnaire to group participants as naïve or sophisticated in their epistemic beliefs. Data analyses revealed that participants with sophisticated epistemic beliefs had multidimensional conceptions of inquiry and provided conceptually rich definitions. Students with naïve beliefs, on the other hand, revealed more simplistic and indistinct conceptions of inquiry and either described it with few details or stated that they did not know about it. The study in general indicated the presence of a relationship between epistemic beliefs and inquiry conceptions, implying that any practical effort to change the way students conceptualize a phenomenon in general and inquiry in particular needs to take into account their epistemic beliefs.
\end{abstract}

\section{Résumé}

La présente étude avait pour objectif d'examiner les conceptions de la recherche scientifique d'étudiants universitaires de premier cycle et la relation entre ces conceptions et leurs croyances épistémiques. Les données de la recherche scientifique de 107 étudiants (80 femmes et 27 hommes) ont été obtenues à l'aide d'un questionnaire à réponses libres servant à 
examiner les conceptions des participants, ainsi que d'un questionnaire sur les croyances épistémiques de Schommer, servant à catégoriser les croyances des participants comme étant naïves ou sophistiquées. L'analyse des données a révélé que les participants ayant des croyances épistémiques sophistiquées avaient également une conception multidimensionnelle de la recherche scientifique et avaient fourni des réponses conceptuellement riches. À l'inverse, les étudiants ayant des croyances épistémiques naïves avaient une conception plus simpliste et indistincte de la recherche scientifique, qu'ils ont décrite soit avec parcimonie, soit en déclarant qu'ils n'en savaient rien. En outre, l'étude révèle une relation entre les croyances épistémiques et les conceptions de la recherche scientifique des étudiants, indiquant que tout effort pour changer la façon dont les étudiants conceptualisent tout phénomène général, et toute recherche en particulier, devrait tenir compte de leurs croyances épistémiques.

\section{Introduction}

In the context of learning and instruction, inquiry is a form of self-directed learning that makes students become more responsible for determining what they need to learn, identifying and using resources that can help them learn in the most efficient and effective way, as well as assessing and reporting self-progress in learning (Henson, 1986; MartinHansen, 2002; Roy, Kustra, \& Borin, 2003). As learning becomes more self-directed, it seems logical to assume that beliefs will play an essential role. Beliefs are instrumental in defining tasks and behaviour: the ways by which individuals interpret, plan, and make decisions about what they do (Kuzborska, 2011; Pajares, 1992; Stipek, Givvin, Salmon, \& MacGyvers, 2001). Hence, they have the potential to promote or impede self-directed learning. Bearing in mind that inquiry is a form of self-directed learning, the way individuals believe about the nature of knowledge likely determines their decisions and actual engagement in inquiry tasks. For example, having an attitude towards knowledge that questions and doubts simplistic answers or solutions promotes willingness to engage in inquiry. Such scepticism is considered an essential habit of mind for engagement in inquiry, and it implies reluctance to accept existing interpretations or the assertions of authorities as final truths; consequently, it instils a desire to find out answers for oneself (Beyer, 1971; Greco, 2000; Llewellyn, 2005).

The generation of problems or questions that lead students to autonomous and active engagement in authentic tasks so that they achieve higher-level learning goals characterizes inquiry learning and instruction. However, enactment of inquiry in classrooms does not always go smoothly. There are potential barriers that hinder its successful implementation (Aulls \& Shore, 2008; Shore, Aulls, \& Delcourt, 2008). A good portion of the literature concerning the challenges and enabling conditions for implementing inquiry learning and instruction has focused on factors outside the individual learner. The National Research Council (NRC, 2000) cited: barriers related to teachers and administrative factors, such as teachers' beliefs and values (about students, teaching, and education); limited teaching abilities; challenges in relation to assessment and new teacher and student roles; inadequate in-service education; resistance from principals and superintendents; lack of resources; and priority being given to content coverage to ensure that students are 
prepared for exams. Roehrig and Luft's (2004) study strengthens the claims of the NRC. Their study examined the constraints experienced by beginning secondary school science teachers in implementing inquiry lessons. They identified the main constraints for the enactment of inquiry to be teachers' understanding of the nature of science and scientific inquiry, content knowledge, pedagogical content knowledge, teaching beliefs, and concerns about management. Aulls and Shore (2008) further added factors related to the learners themselves as potential impediments. Students' risk-taking behaviour, content knowledge, readiness to take responsibility, motivation, and thoughtfulness were identified as impeding or enabling factors for inquiry learning and instruction.

One matter worth considering in relation to success in inquiry learning and instruction is the role students' beliefs about knowledge and knowing (epistemic beliefs) may play in their engagement as well as their understanding of inquiry. There is considerable empirical support for the role of epistemic beliefs in students' learning. Epistemic beliefs influence motivation to learn (e.g., Bråten \& Strømsø, 2004; Muis \& Franco, 2009; Ravindran, Greene, \& Debacker, 2005), learning strategy use (e.g., Chan, 2007; Dahl, Bals, \& Turi, 2005; Phan, 2008; Schommer-Aikins \& Easter, 2008), and subsequent performance (e.g., Bendixen \& Hartley, 2003; Schommer, 1990; Schommer \& Walker, 1995). Studies have indicated that students with sophisticated epistemic beliefs (beliefs that knowledge is self-constructed and uncertain) are more likely to adopt mastery goal orientation than those with naïve beliefs (beliefs that knowledge is simple and certain) (Bråten \& Strømsø, 2004; 2005; Muis \& Franco, 2009). In relation to learning strategy use, some reports have shown that students with sophisticated beliefs use a wider variety of deep or meaningful strategies than students with naïve beliefs (Chan, 2007; Dahl, Bals, \& Turi, 2005); Ravindran et al. 2005). Concerning their relation to learners' performance, beliefs about knowledge and knowing have been found to be significant predictors of performance in passage comprehension tasks (Schommer \& Walker, 1995) as well as in short answer and comprehension tasks (Bendixen \& Hartley, 2003).

However, the possible relationship of epistemic beliefs to students' engagement and understanding of inquiry is missing from this body of research. Hence, the specific purpose of the present study was to examine undergraduate students' inquiry conceptions and the relationship of the inquiry conceptions to epistemic beliefs.

\section{Literature Review}

\section{Inquiry}

Inquiry is a multifaceted concept that has no single agreed upon definition (Anderson, 2002; Aulls \& Shore, 2008). In expressing the difficulty of defining inquiry, authorities state that it is easier to agree on what inquiry is not rather than what it is (DuVall, 2001; Minstrell, 2000). Despite the disagreement, the integration of inquiry into the regular school curriculum in North America has been widely advocated for more than three decades (Aulls \& Shore, 2008).

Inquiry helps learners become active, efficient problem solvers and critical thinkers so that they can effectively apply their knowledge (Manconi, Aulls, \& Shore, 2008). The characteristics of inquiry-based learning and instruction include generating questions/problems, the autonomous and active engagement of learners, task authenticity, and a focus on 
higher-level learning goals. Empirical evidence shows that inquiry learning and instruction help to enhance conceptual understanding (McNeal, Miller, \& Herbert, 2008; Nugent, Kunz, Levy, Harwood, \& Carlson, 2008; Wallace, Tsoi, Calkin, \& Darley, 2003), the development of learning skills and strategies (Brickman, Gormally, Armstrong, \& Hallar, 2009; Fuselier, Bougary, \& Malott, 2011; Quitadamo, Faiola, Johnson, \& Kurtz, 2008), as well as the application of learning (Hurd, 2008; Iqbal \& Chowdhury, 2007). However, inquiry has to be well understood if it is to be successfully implemented in classroom instruction. To this end, part of the task is to understand the conceptions students have about inquiry and its relationship with other potential cognitive pre-requisites, such as epistemic beliefs.

\section{Epistemic Beliefs}

Research concerned with beliefs of individuals about knowledge and knowing has used varying terminology (Hofer, 2001) but often with a very similar focus. Terms include intellectual and ethical development (Perry, 1970), epistemological reflection (Baxter Magolda, 1992), reflective judgment (King \& Kitchener, 1994), argumentative reasoning (Kuhn, 1991), ways of knowing (Belenky, Clinchy, Goldberger, \& Tarule, 1986), epistemological beliefs (Jehng, Johnson, \& Anderson, 1993; Schommer, 1990), and epistemic beliefs (e.g., Muis, Bendixen, \& Haerle, 2006). The most recent tendency is the usage of the term "epistemic beliefs." This is also the term used throughout this study to connote beliefs about knowledge and knowing.

In addition to employing such variations in terminology, scholars have discussed epistemic beliefs from three perspectives: (a) developmental, (b) multidimensional, and (c) contextual/integrated; (c) includes both the context (Hammer \& Elby, 2002; Muis et al., 2006) and the mechanisms of change (Bendixen \& Rule, 2004). Of these, the multidimensional perspective, in particular Schommer's (1990) model, is often used as an orienting framework for studies on beliefs about knowledge and knowing (see, for example, Boden, 2005; Paulsen \& Feldman, 1999; Phan, 2008). Furthermore, measures of epistemic beliefs in later studies are mainly adapted from Shommer's Epistemological Beliefs Questionnaire (EBQ) (e.g., Hofer, 2000; Schraw, Bendixen, \& Dunkle, 2002). Hence, in the present study, the EBQ was used to examine the participants' epistemic beliefs.

Schommer (1990) hypothesized that beliefs about knowledge have more or less independent dimensions, each of which can be classified in a range from naïve to sophisticated. She proposed a five-dimensional model consisting of beliefs about: (a) control of knowledge acquisition/ability to learn (from inherited and unchangeable to improvable over time), (b) speed of knowledge acquisition/learning (from learning occurs quickly or not at all to learning is gradual), (c) certainty (stability) of knowledge (from knowledge is certain, unchanging, or absolute to knowledge is constantly changing), (d) structure (simplicity) of knowledge (from knowledge is organized as isolated bits and pieces to knowledge is organized as highly interrelated concepts), and (e) source of knowledge (from knowledge is handed down by omniscient authority to knowledge is acquired through reason or logic).

As well as hypothesizing about the presence of more or less independent dimensions, Schommer characterized epistemological beliefs as frequency distributions rather than dichotomies (Schommer-Aikins, 2002)-i.e., an individual may believe that most knowledge is certain and some knowledge is uncertain or vice versa. Furthermore, the development of epistemic beliefs may not occur synchronously. In other words, change in an in- 
dividual's belief about the certainty of knowledge does not imply change in his/her belief about the structure of knowledge (Schommer-Aikins, 2002).

Two of Schommer's dimensions-innate ability and quick learning-were criticized as being outside the construct of epistemic beliefs. According to Hofer and Pintrich (1997), innate ability is about the nature of intelligence rather than about beliefs about knowledge. Though it may be indirectly related to learning and motivation, they claimed, "it is not clearly a dimension regarding the nature of knowledge" (Hofer \& Pintrich, 1997, p. 109). Similarly, quick learning represents individuals' perceptions of task difficulty rather than indicating a belief about knowledge (Hofer \& Pintrich, 1997). However, certainty and simplicity are common dimensions of beliefs about knowledge and knowing in many models and empirical studies pertaining to epistemic beliefs (Chan \& Elliott, 2004a; Hofer \& Pintrich, 1997; Schommer, 1998; Yilmaz-Tuzun \& Topcu, 2008). Hence, in the present study, these latter two dimensions are considered to examine participants' epistemic beliefs.

\section{The Relationship between Epistemic Beliefs and Students' Conceptions/Un- derstandings of Inquiry}

To date, no study has directly examined the relationship between epistemic beliefs and students' conceptions/understandings of inquiry. However, the possibility of such a relationship can be inferred from theoretical and empirical claims about the relationship between epistemic beliefs and conceptions of learning and teaching. In addition, there is evidence that epistemic sophistication relates to the tendency to become more reflective, critical, and detailed in thoughts about and explanations of phenomena. Such evidence can also serve as a base to examine the extent to which epistemic sophistication is related to the ways students tend to describe their understanding of what inquiry is.

One theoretical proposition about the relationship between epistemic beliefs and learning conceptions was offered by Entwistle and Peterson (2004). Drawing on Perry's (1970) stages of intellectual and ethical development, and Säljö's (1979) and Marton et al.'s (1993) categories of learning conceptions, the model shows that there is a corresponding relationship between the two constructs. More specifically, at the naïve level of epistemic beliefs (in which individuals have a dualistic view about knowledge), learning is regarded as the acquisition of factual information and is equated with memorization. In contrast, at the sophisticated level of epistemic beliefs (in which individuals view knowledge as relative and personal), learning is regarded as a process of seeking meaning.

Others have offered empirical evidence that supports theoretical models of the relationship between epistemic beliefs and conceptions of learning (Chan, 2007, 2011; Zhu, Valcke, \& Schellens, 2008). For example, Zhu et al. (2008) proposed a theoretical model showing the relationships among epistemic beliefs, conceptions of learning, and approaches to study. The model was proposed based on Schommer's (1994) dimensions of beliefs about knowledge and four of the six dimensions of learning conceptions proposed by Purdie and Hattie (2002). Analysis using structural equation modeling largely confirmed the theoretical propositions. In particular, belief in the certainty of knowledge positively predicted the conception of learning as remembering, and strong relationships were observed between the belief that ability changes over time and constructivist conceptions of learning (learning as using and understanding information, as personal change, as the development of social competence). Chan's $(2007,2011)$ studies also confirmed the presence of a relationship between epistemic beliefs and learning conceptions. Such em- 
pirical investigations in general showed that students with sophisticated epistemic beliefs reveal qualitative conceptions of learning (e.g., learning as understanding, learning as changing a person), compared to students with naïve epistemic beliefs, who demonstrate quantitative conceptions of learning (e.g., learning as an increase in knowledge, and the memorization of information).

Similarly, the way teaching, and hence instruction, is conceptualized relates to epistemic beliefs. Entwistle, Skinner, Entwistle, and Orr (2000) proposed a model relating epistemic beliefs to conceptions of teaching, based on Perry's (1970) stages of intellectual development and Kember's (1997) classifications of teaching conceptions. The model demonstrates that sophisticated epistemic beliefs are aligned with student-centered/ learning-oriented teaching conceptions, whereas naïve epistemic beliefs are aligned with teacher-centered/content-oriented teaching conceptions. Empirical studies that examined the relationship of student-teachers' epistemic beliefs to conceptions of teaching (Chan \& Elliott, 2004b; Cheng, Chan, Tang, \& Cheng, 2009; Wong, Chan, \& Lai, 2009) and to instructional preferences and styles of teaching (Sosu \& Gray, 2012) also revealed that student-teachers with sophisticated epistemic beliefs mostly endorsed constructivist conceptions of teaching and preferred student-centered styles compared to studentteachers with naïve epistemic beliefs, who mostly endorsed traditional conceptions of teaching and preferred teacher-centered styles of teaching.

With the above-mentioned supporting evidence on the relationship between epistemic beliefs and conceptions of learning and teaching, it is viable to hypothesize that there is a potential relationship between epistemic beliefs and conceptions (understandings) of inquiry. Epistemic beliefs may well comprise the underlying factors influencing the ways by which students conceptualize inquiry.

It is also possible to make inferences about the relationship between epistemic beliefs and inquiry conceptions based on claims concerning the role epistemic sophistication plays in individuals' tendency to become more reflective, critical, and detailed in thinking about and providing explanations for phenomena. Studies indicate that sophistication of epistemic beliefs relates to provision of detailed information and rich narratives of phenomena (Liu \& Lederman, 2007; Liu \& Tsai, 2008; Nussbaum, Sinatra, \& Poliquin, 2008). For example, Liu and Tsai (2008) have found that compared to students with sophisticated scientific epistemological views, those with naïve views wrote shorter and less detailed answers to questions that asked them to define what science is and what makes it different from other disciplines of inquiry. In contrast, the sophisticated students more often elaborated their thoughts than did the naïve students. Similarly, Liu and Lederman (2007) found that students who were grouped as naïve in their views about the nature of science (NOS) were not often reflective enough to provide comments on questions that were intended to investigate their world views. Comparison of the interview narratives of those with relatively sophisticated NOS views (those who viewed science as tentative, subjective, etc.) to those with naïve NOS views (those who viewed science as certain, objective, etc.) revealed that students in the former group provided rich information in their narratives and were more reflective than those in the latter group. Nussbaum et al. (2008) investigated the role of students' epistemic beliefs in the quality of their arguments while engaging in an online learning environment. The researchers used Khun, Cheney, and Weinstock's (2000) framework of examining epistemic beliefs as absolutist, multiplist, and evaluativist to classify the students' epistemic orientation. The quality of arguments was examined in terms 
of the extent to which different ideas were integrated in the arguments. Compared to absolutists and multiplists, evaluativists tended to bring different ideas and raised more issues.

In summary, the cited empirical studies have shown that the epistemic stances of individuals influence their tendency to be more reflective, critical, and detailed in their thoughts and in the degree and nature of the arguments and explanations they provide. Hence, it is viable to hypothesize that students with sophisticated epistemic beliefs are likely to define and explain inquiry in a more detailed and elaborate manner than students with naïve epistemic beliefs.

\section{Methodology}

\section{Participants}

Two hundred and twelve undergraduate students (166 = female, $46=$ male) were involved in the study, from three universities: two in Québec and one in the north east of the United States. One hundred and three of them were in their first year of studies, 45 in their second, 31 in their third, 19 in their fourth, and nine in their fifth. Five participants either did not report or provided unclear reports. After the remaining 207 students completed Schommer's questionnaire, only those who were identified as sophisticated ( $n=$ $54)$ or as naïve $(n=53)$ in their epistemic beliefs were included in the final analysis.

\section{Instruments}

Open-ended questionnaire. An open-ended questionnaire was used to examine participants' conceptions of inquiry. The questionnaire consisted of three questions, asking the participants to: (1) write their own definition of inquiry and explain its importance; (2) imagine and describe a classroom scenario in which the teacher and students engaged in good teaching and learning; and (3) explain whether the students themselves had experienced such a classroom - and, if so, to specify the level at which they had experienced it. The questionnaire had been used in our own and other earlier investigations of students' understanding of inquiry (Getahun, Aulls, \& Saroyan, 2014; Syer, 2007). For the purpose of the present investigation, only responses given to the first question were analyzed to depict participants' conceptions of inquiry. In prior studies, conceptions, such as those about learning, were examined in a similar manner by asking participants a single question that required students to define what learning meant to them (Säljö, 1979).

Schommer's epistemological beliefs questionnaire. This was used to identify participants with either sophisticated or naïve views about knowledge. The questionnaire is composed of 63 items. It uses a five-point rating scale, ranging from 1 (strongly disagree) to 5 (strongly agree), to measure four dimensions of epistemic beliefs: certainty, simplicity, quick learning, and innate ability. The reliability estimates for each of the factors with a sample of college students has been reported to be in the range of 0.63 to 0.85 (Duell \& Schommer-Aikins, 2001). Based on the data in the present study, the Cronbach's alpha reliability estimate for the overall scale was found to be 0.78 , and the estimates for the subscales ranged from 0.65 to 0.79 . The design of the questionnaire was such that lower scores would indicate sophisticated beliefs about knowledge and higher scores would indicate naïve beliefs. Twenty-seven items needed reverse scoring.

As noted earlier, only the dimensions of certainty and simplicity were used to identify sophisticated and naïve students, because these dimensions occur most consistently in 
various models of epistemic beliefs (Chan \& Elliott, 2004a; Hofer \& Pintrich, 1997; Schommer, 1998). In order to classify participants as naïve or sophisticated, the median scores on the two dimensions were used. That is, those who scored above the median on both dimensions were considered naïve, and those who scored below the median on both dimensions were considered sophisticated. This was done to obtain groups with the maximum potential variation in the sophistication of their epistemic beliefs. Muis (2004) used a somewhat similar procedure when applying the Psycho-Epistemological Profile questionnaire to identify students who were predominantly rational in their views about knowledge and those who were predominantly empirical. The classification procedure resulted in $54 \mathrm{stu}-$ dents (female $=41$, male $=13$ ) being in the naïve group and $53($ female $=39$, male $=14)$ being in the sophisticated group. Data from these participants were used in the final analysis about the relationship between epistemic beliefs and conceptions of inquiry.

\section{Data Analyses Procedures}

Identification of inquiry conceptions. Open coding and constant comparison (Strauss \& Corbin, 1998) were conducted on the participants' definitions and explanations of the importance of inquiry, to examine the ways by which they conceptualized inquiry. Initial inter-coder reliability (on about $20 \%$ of randomly selected definitions) between two independent coders-the first author and one of the co-authors-was $81 \%$ before discussion. Once the categories were agreed through thorough discussion, another round of reliability checking resulted in $92 \%$ agreement before discussion.

The relationship between inquiry conceptions and epistemic belief groupings. After categories of inquiry conceptions were identified through open coding and constant comparison, the frequencies of the subcategories and superordinate categories of the inquiry conceptions were examined for the naïve and the sophisticated epistemic belief groups, and the presence of association between inquiry conceptions and epistemic belief groupings were checked using the chi-square test.

Scoring of inquiry definitions. The participants' definitions of inquiry were assigned scores meant to represent conceptual richness and the extent to which the participants had focused on the most central concepts (as judged by experts in the area of inquiry) in their definitions of inquiry. The procedure used to assign scores was adapted from the concept-map scoring mechanism employed by Rye and Rubba (2002), wherein the concept maps students used to reveal their understanding were judged and scored in terms of the extent to which they contained essential concepts.

In the present study, in order to assign scores, we prepared a five-point rating scale that contained 13 subcategories of inquiry conceptions, generated from open coding and constant comparison of the participants' definitions, and we requested experts-who were known educators, particularly in the area of inquiry learning and instruction-to rate them; the experts were selected based on their work and contributions in the area of inquiry learning and instruction. Initially, 16 identified experts received the rating scale through emails. Out of these, 10 responded. The experts were asked to judge the extent to which the concept in each subcategory of inquiry conception was central (basic) in representing what inquiry is. In other words, it was assumed that the categories tended to vary in their conceptual strength with respect to representing an "ideal" inquiry. The ratings for each subcategory were added up. Based on the scores, we put the subcategories into three classes with respect to describing what inquiry is: the top four subcategories (in- 
quiry as a means of problem solving, inquiry as a means of self-learning and knowledge construction, inquiry as a means of empowering students, and inquiry as teaching for in-depth understanding) represent highly central concepts, the middle five subcategories (inquiry as a means of developing knowledge, inquiry as researching for understanding, inquiry as an adaptive form of teaching, inquiry as an active/interactive form of teaching, and inquiry as discovery) represent medially central concepts, and the bottom four subcategories (inquiry as a means of gaining information/knowledge, inquiry as hypothesis testing/hypothesizing, inquiry as a means of improving practice, and inquiry as a tool for assessment) represent less central concepts.

Following this, weighted scores were assigned: a score of 3 for those classified as highly central, a score of 2 for those classified as medially central, and a score of 1 for those classified as less central. Where definitions occurred with concepts belonging to more than one subcategory (double-coded definitions), the respective weighted scores were added. That is, if a participant's definition contained concepts belonging to two subcategories, one classified as highly central and the other as medially central, two scores were assigned and added (e.g., $3+2=5$ ). On the other hand, inquiry definitions categorized as indistinct were assigned a score of 0 .

Differences between epistemic belief groups in conceptual richness of inquiry definitions. Following the assignment of scores for the inquiry definitions based on the scoring scheme developed, a $t$ test was run using the groupings based on epistemic beliefs (naïve and sophisticated) as the independent variable and the participants' scores on inquiry definitions as the dependent variable, to examine differences between the two groups with regard to the conceptual richness of their inquiry definitions.

\section{Results}

\section{Conceptions of Inquiry}

Open coding and constant comparison of significant idea units obtained from the participants' definitions of inquiry and explanations of its importance yielded 13 subcategories of inquiry conceptions: (a) gaining information/knowledge, (b) developing knowledge, (c) self-learning and knowledge construction, (d) adaptive form of teaching, (e) a means of empowering students, (f) an active/interactive form of teaching, (g) teaching for in-depth understanding, (h) a tool for assessment, (i) problem solving, (j) hypothesis testing/hypothesizing, (k) researching for understanding, (l) discovery, and (m) improving practice.

Furthermore, definitions in which the participants either did not explicitly indicate a goal and/or process of inquiry, or demonstrated that they had no idea about inquiry, or defined inquiry in a vague and very broad manner, were categorized separately as indistinct categories. Closer examination of the derived subcategories indicated that they could be grouped into three superordinate conceptual categories: inquiry as a learning process, inquiry as an instructional process, and inquiry as a research/scientific process. Repeated constant comparison of the complete set of definitions was conducted to ensure that all student definitions of inquiry were accounted for by the primarily in vivo and lowinference subcategories, as well as by the broader, researcher-generated superordinate conceptual categories. Table 1 presents the superordinate and subordinate categories of the inquiry conceptions, as well as sample excerpts from the participants' definitions. 


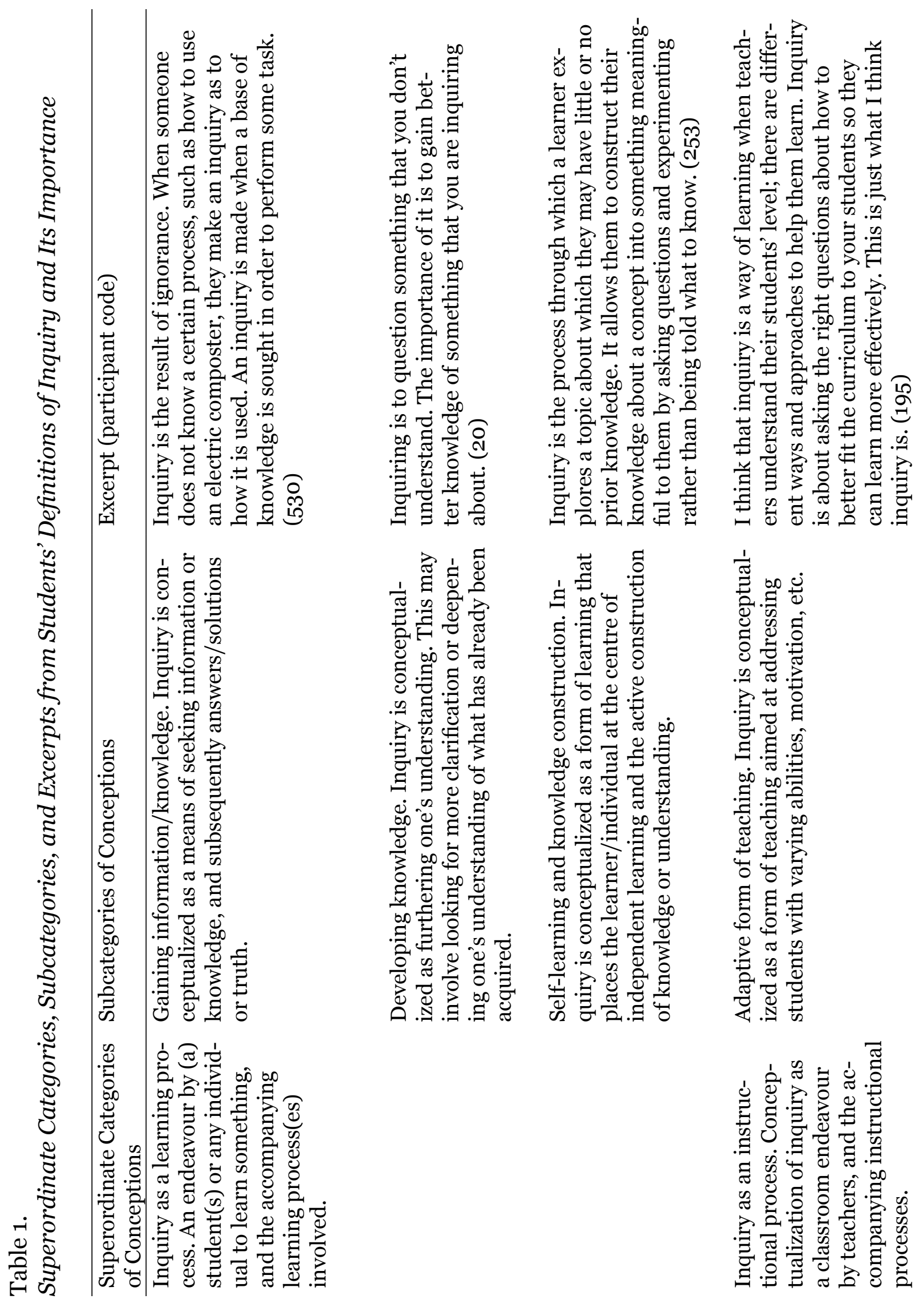



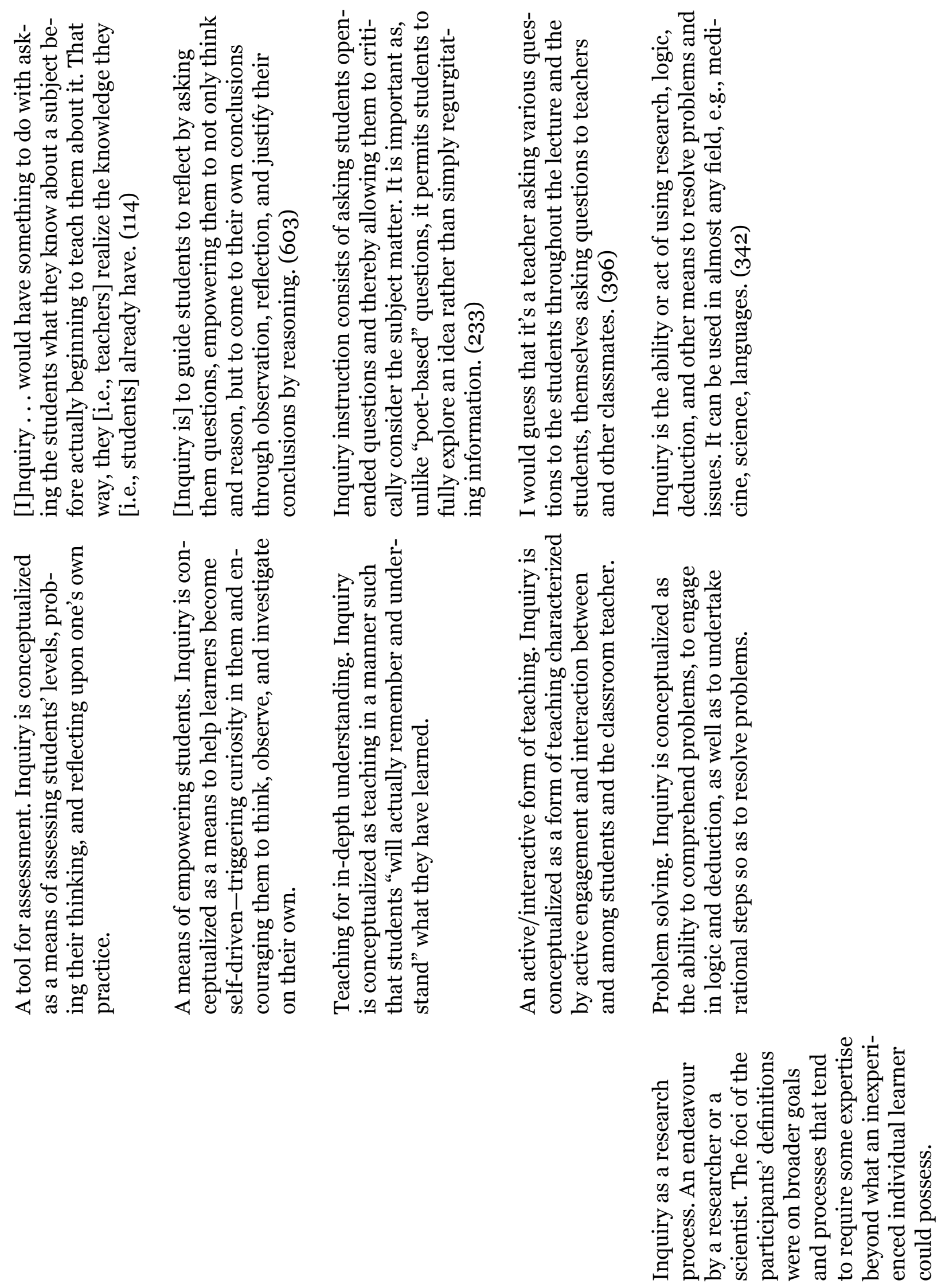

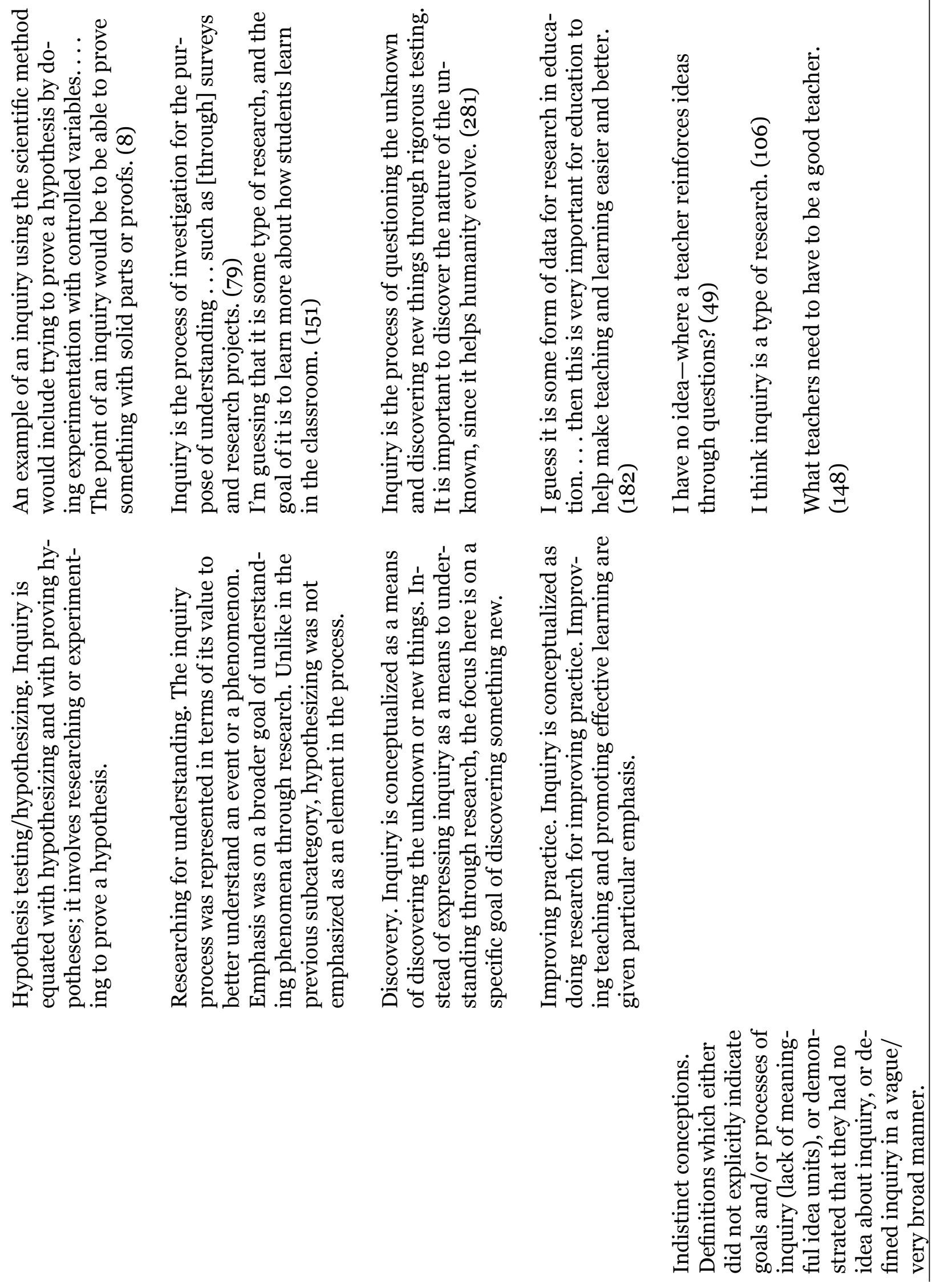


\section{The Relationship between Conceptions of Inquiry and Epistemic Beliefs}

Frequency distributions were examined for subcategories of inquiry conceptions for the naïve and the sophisticated groups. Inquiry as a means of gaining information/knowledge proved to be the most prevalent subcategory in both the naïve and the sophisticated groups, followed by inquiry as a means of developing knowledge. Among the definitions categorized as indistinct, $80 \%$ of them were from students classified as naïve in their epistemic beliefs.

Table 2.

Frequency and Percentage Distribution of the Subcategories of Inquiry Conceptions by Epistemic Belief Groups

\begin{tabular}{lccc}
\hline & \multicolumn{2}{c}{ Epistemic Belief Groups } & \\
\cline { 2 - 3 } Subcategories of Inquiry Conceptualization & Naïve & Sophisticated & Total \\
\hline Gaining information/knowledge & $(n=54)$ & $3053)$ & 30 \\
Developing knowledge & $15(27.78 \%)^{*}$ & $15(28.30 \%)$ & 23 \\
Self-learning and knowledge construction & $9(16.67 \%)$ & $14(26.42 \%)$ & 14 \\
An adaptive form of teaching & $6(11.11 \%)$ & $8(15.09 \%)$ & 5 \\
A tool for assessment & $2(3.70 \%)$ & $3(5.66 \%)$ & 7 \\
Teaching for in-depth understanding & $2(3.70 \%)$ & $5(9.43 \%)$ & 4 \\
Active/interactive form of teaching & $0(0 \%)$ & $4(7.55 \%)$ & 14 \\
Empowering students & $5(9.26 \%)$ & $9(16.98 \%)$ & 12 \\
Discovery & $2(3.70 \%)$ & $10(18.87 \%)$ & 2 \\
Hypothesis testing/hypothesizing & $2(3.70 \%)$ & $0(0 \%)$ & 1 \\
Researching for understanding & $1(1.85 \%)$ & $0(0 \%)$ & 4 \\
Problem solving & $1(1.85 \%)$ & $3(5.66 \%)$ & 14 \\
Improving practice & $3(5.56 \%)$ & $1(1.89 \%)$ & 4 \\
Indistinct categories & $1(1.85 \%)$ & $1(1.89 \%)$ & 2 \\
\hline
\end{tabular}

*Percentages are calculated based on the actual number of students in each group. Since there were doublecoded definitions (i.e., definitions containing ideas that belonged to more than one category), there was double counting of frequencies, which resulted in the summation of percentages exceeding 100.

There were definitions that contained concepts belonging to more than one subcategory and hence were double coded. These are labeled multifaceted definitions (conceptualizations) of inquiry. Figure 1 shows the extent to which a subcategory occurred independently and in combination with other subcategories in each of the epistemic belief groups. 


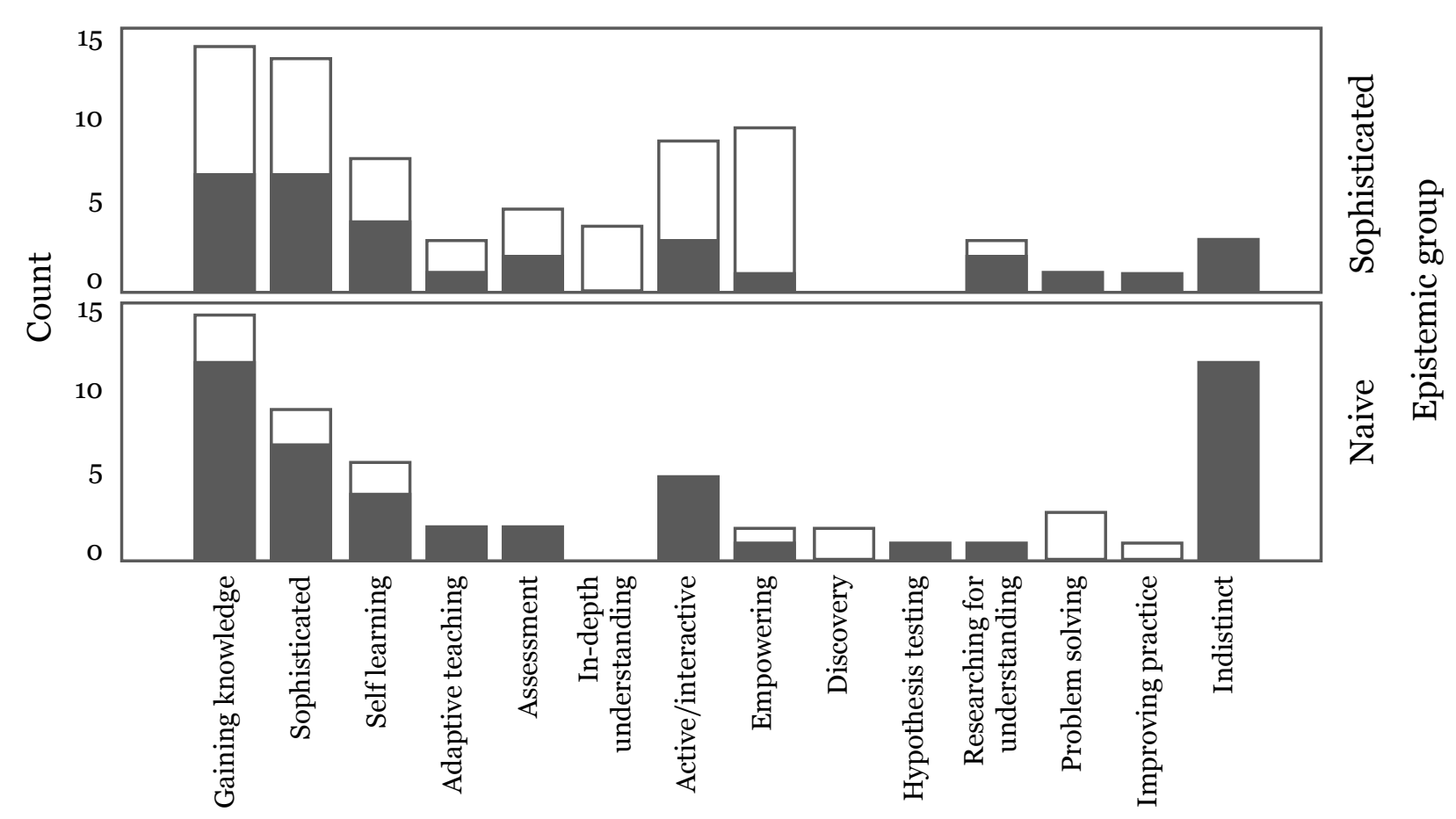

White area $=$ combined occurrence; Dark area $=$ independent occurrence

Figure 1. Independent and double-coded frequency occurrences of subcategories of inquiry conceptualizations for naïve and sophisticated students.

As is evident from Figure 1, excluding the indistinct definitions, out of the observed 11 categories among the sophisticated group, nine (81.8\%) occurred in combination with other subcategories. In most of these (eight out of the nine), the magnitude of combined occurrences was considerable and comprised more than half of the frequency of each subcategory. For example, out of 10 definitions that represented inquiry as a means of empowering students, nine occurred in combination with other subcategories. The following excerpts show the overlapping of the subcategory inquiry as a means of empowering students with inquiry as teaching for in-depth understanding and inquiry as an active/ interactive form of teaching, respectively.

[I]nquiry is related to the critical approach; it is allowing [encouraging] the students to take initiative and ask questions in order to find a greater meaning which will then lead to more questions and possibly controversial issues. It is finding out about the subject matter beyond what is offered in textbooks. It is a means of discussion and being curious. It allows the student to want to go beyond in search of answers that will only lead to more questions. (553)

I think that inquiry is a means of education wherein the students have a type of student-teacher relationship where they can ask any questions in order to learn. Students don't just sit and listen but actively participate in acquiring knowledge through inquiry. Students may be presented with several questions that get them to have to think independently and question/observe/investigate in order to come to a conclusion of what the answer could be. (305) 
In contrast, not only was the extent of combined occurrences of subcategories in the naïve group limited, but the magnitude of overlap was also very small. Out of the observed 12 subcategories, seven (58.39\%) occurred in combination with others, and for most of these, only small portions overlapped with other subcategories.

In order to examine whether there was a significant association between inquiry conceptions and epistemic belief groupings, a chi-square test was run. For running the chisquare $\left(\chi^{2}\right)$ analysis, three necessary precautions needed to be taken into account: (a) every observation should fall into one and only one category (cell), (b) there should not be a cell without an observation, and (c) not more than $20 \%$ of the cells should have an expected frequency of less than five (Frank \& Althoen, 1994). It was difficult to uphold these precautions when taking the 13 subcategories of conceptions as the basis for running the chi-square analysis. So, the three superordinate categories (inquiry as a learning process, inquiry as an instructional process, and inquiry as a research process), the indistinct category, and another derived category-the multifaceted category-were used for the analysis. The multifaceted category represented inquiry definitions that contained multiple concepts and hence were double coded for two or more subcategories.

Table 3. Frequency Distribution of the Superordinate Categories of Inquiry Conceptions by Epistemic Belief Groups

\begin{tabular}{lccc}
\hline Category (Inquiry as...) & Naïve & Sophisticated & Total \\
\hline a learning process & 23 & 18 & 41 \\
an instructional process & 10 & 7 & 17 \\
a research/scientific process & 2 & 4 & 6 \\
multifaceted & 7 & 21 & 28 \\
indistinct & 12 & 3 & 15 \\
Total & 54 & 53 & 107 \\
\hline
\end{tabular}

Figure 2 shows that while there were more multifaceted definitions from the sophisticated group, there were more indistinct definitions from the naïve group.

The results of the chi-square test indicated statistically significant associations between the five categories of inquiry conceptions and the epistemic belief groups (Table 4). To determine which cells contributed most to the association, standardized Pearson residuals (adjusted residuals) of the cells were observed (Agresti, 2002). The obtained chi-square statistic was also converted into Cramér's V to get a comparative statistic that shows the strength of the observed relationships between the two variables (Kerlinger, 1986; Leech, Barrett, \& Morgan, 2005). According to Agresti (2002), adjusted residual values that exceed 2 in absolute value indicate that the frequency of a cell contributes significantly to the association. Based on this criterion, it was evident that the multifacet$e d$ and indistinct categories mainly contributed to the association between the epistemic groups and the categories of conceptions. From the frequencies, we observed that more students from the sophisticated group provided multifaceted definitions (definitions that addressed different subcategories) than students in the naïve group. On the other hand, many of the indistinct definitions (12 out of 15) were from the naïve group. 


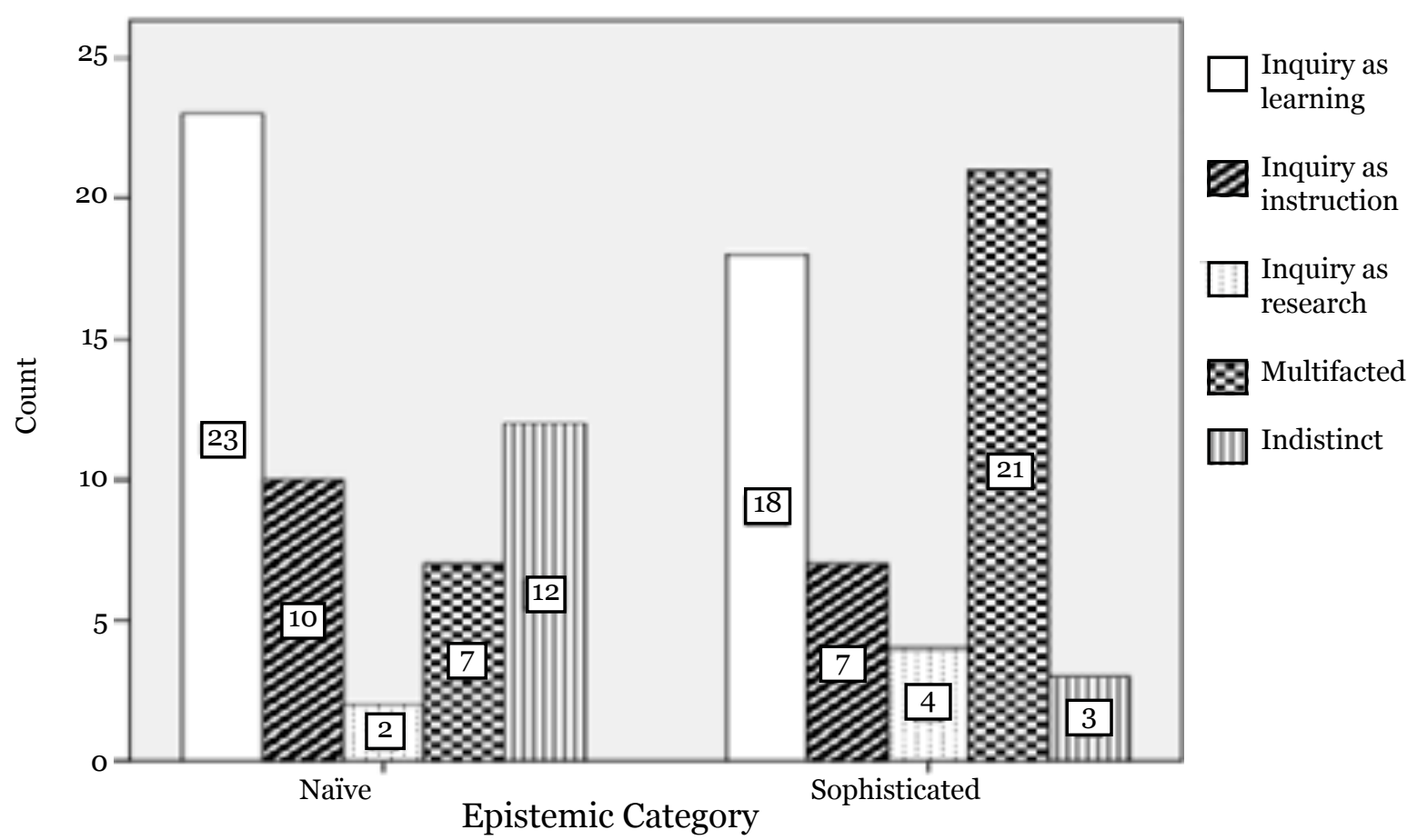

Figure 2. Frequency of inquiry conception categories for naïve and sophisticated groups.

Table 4.

Association between Superordinate Categories of Inquiry Conceptions and Epistemic Belief Groups

\begin{tabular}{lcccccc}
\hline Category (Inquiry as...) & Naïve & Sophisticated & Total & $\chi^{2}$ & $d f$ & $p$ \\
\hline a learning process & 23 & 18 & 41 & 14.198 & 4 & 0.007 \\
an instructional process & 10 & 7 & 17 & & & \\
a research/scientific process & 2 & 4 & 6 & & & \\
multifaceted & 7 & 21 & 28 & & & \\
indistinct & 12 & 3 & 15 & & & \\
Total & 54 & 53 & 107 & & & \\
\hline
\end{tabular}

Table 5.

Adjusted Residuals and Cramér's V Equivalent of the Chi-square Statistic of Association between Categories of Inquiry Conceptions and Epistemic Belief Groups

\begin{tabular}{lcccc}
\hline & \multicolumn{2}{c}{ Epistemic Belief Group } & & \\
\cline { 2 - 3 } Category (Inquiry as...) & Naïve & Sophisticated & Cramér's V & $p$ \\
\hline a learning process & 0.9 & -0.9 & 0.36 & 0.007 \\
an instructional process & 0.8 & -0.8 & & \\
a research/scientific process & -0.9 & 0.9 & \\
multifaceted & -3.1 & 3.1 & \\
indistinct & 2.5 & -2.5 & \\
\hline
\end{tabular}




\section{Differences in Conceptual Richness of Definitions between the Epistemic Belief Groups}

In addition to examining the relationships between categories of inquiry conceptions and epistemic belief groupings, a $t$ test was used to compare the naïve and sophisticated students' mean scores of inquiry definitions so as to examine differences in the conceptual richness of the definitions and the extent to which students had focused on the most central concepts in their definitions of inquiry. The purpose of this analysis was to examine whether there was statistical variation in the epistemic belief groups' conceptions of inquiry.

After scoring the definitions based on the procedure described earlier, a $t$ test was used to compare the means of the naïve and the sophisticated epistemic groups. The result revealed a statistically significant mean difference, $t(105)=-3.478, p<.001$, in favour of the sophisticated group students, with an effect size of 0.73 (see Table 6). The obtained effect size shows the presence of a moderate effect of epistemic beliefs on inquiry conceptions.

Table 6.

Mean Differences in Inquiry Conception Scores between Epistemic Belief Groups

\begin{tabular}{lccccccc}
\hline Epistemic Group & $n$ & Mean & $S D$ & $t$ & $d f$ & $p$ & Effect Size \\
\hline Naïve & 54 & 1.69 & 1.412 & -3.478 & 105 & $<.001$ & 0.73 \\
Sophisticated & 53 & 2.87 & 1.830 & & & & \\
\hline
\end{tabular}

\section{Discussion}

In both the chi-square and the $t$ test analyses, participants with sophisticated epistemic beliefs had well-informed conceptions of inquiry compared to those with naïve epistemic beliefs. The level of simplicity or complexity of conceptions (indistinct, multidimensional) was found to be much more important than categories of conceptions (learning, instruction, and research) in defining the relationship between epistemic beliefs and conceptions of inquiry. Students with sophisticated epistemic beliefs depicted more multidimensional conceptions of inquiry. That is, they provided descriptions of inquiry with better details and exhibited multiple conceptions or diversified ways of looking at inquiry. Students in the naïve grouping, on the other hand, revealed more simplistic and indistinct definitions of inquiry and described it either with few details or stated that they did not know about it.

The presence of a relationship between epistemic beliefs and conceptions is evident from earlier empirical studies. For instance, studies have revealed that students with sophisticated epistemic beliefs adopt constructivist conceptions of learning while those with naïve beliefs adopt more traditional conceptions (e.g., Aypay, 2010; Chan, 2007, 2011; Otting, Zwaal, Tempelaar, \& Gijselaers, 2010). The present study complements these findings by adding another dimension, namely students' conception of a particular phenomenon-inquiry-and its relationship to epistemic beliefs. Even though the designs of earlier studies as well as the present study do not explicitly allow the inferring of a causal link between epistemic beliefs and conceptions, the consistency of the results in showing the presence of a relationship between the two constructs highlights the possible role epistemic beliefs may play as underlying factors in conceptualizing phenomena. 
Empirical studies also have shown that with epistemic sophistication, there is a tendency for thinking to be more reflective, critical, and detailed. For instance, studies by Liu and Lederman (2007), Liu and Tsai (2008), and Nussbaum et al. (2008) have shown that epistemologically sophisticated students are more able and willing to elaborate upon their thoughts and to provide more complex, detailed, and different ideas in their writings and interview narratives, and tend to be more reflective than epistemologically naïve students. It can, therefore, be cautiously concluded that the sophisticated students' multifaceted conceptions of inquiry in the present study might be due to their ability to look at and interpret phenomena comprehensively.

In summary, the current study informs us about the difference in the extent of detail that students with naïve or sophisticated epistemic beliefs provide in interpreting as well as explaining scientific phenomena. Furthermore, the apparent relationship between epistemic beliefs and conceptions of inquiry suggests that any practical effort to change the way students conceptualize a phenomenon should also take into account their epistemic beliefs. Based on an examination of empirical studies (e.g., Chan \& Elliott, 2004b; Otting et al., 2010; Wong et al., 2009; Zhu et al., 2008), there seems to be a wider assumption that epistemic beliefs are predictors of conceptions. Hence, if the ways individuals believe about knowledge and knowing influence their conceptions of phenomena, starting changes at epistemic beliefs will have a foundational influence. Similarly, in the present study, as sophisticated beliefs about knowledge were found to be related to conceptually rich/informed or multidimensional conceptions, it is worthwhile to enhance students' epistemic beliefs. Engaging students to reflect upon and become more aware of their own thinking and beliefs (Brownlee, Purdie, \& Boulton-Lewis, 2001) as well as teaching them through argumentation and collaborative debate (Bell \& Linn, 2002) are important ways to bring about change in epistemic beliefs, which can in turn influence conceptions of phenomena, one among which is inquiry.

\section{Suggestions for Future Research}

The findings from the study indicated that differences in conceptualizing inquiry were evident between students with naïve and sophisticated epistemic beliefs. However, there are still research gaps on related issues that can serve as paths for future investigation. Four potential issues are suggested below.

1. In the present study, we examined conceptions of inquiry in terms of epistemic belief differences. We assumed that the relation between the variables would be more evident if we considered participants with maximum variations in epistemic beliefs. We considered the dimensions of certainty and simplicity together to categorize the participants as naïve or sophisticated in their epistemic beliefs. One issue for future investigation may be to focus on examining conceptions of inquiry relative to the separate dimensions of epistemic beliefs. This would help to understand whether beliefs about the certainty or simplicity of knowledge matter more in students' understanding of and engagement in inquiry.

2. The present study has employed a broad classification of the participants as naive or sophisticated in their epistemic beliefs, based on Schommer's Epistemological Beliefs Questionnaire. Conducting a qualitative study could help to further strengthen the claims made in the present study about the presence of a relation- 
ship between conceptions of inquiry and beliefs about knowledge. This could be done by asking students to define both "inquiry" and "knowledge" and to explain the nature of knowledge. Possible research questions might include: Can there be a relationship between the way students define what "inquiry" is and what "knowledge" is? Is there any relationship between students' conceptions of inquiry and their characterization of the nature of knowledge?

3. Another issue worth considering for future research is examining the relations between inquiry conceptions and epistemic beliefs relative to specific disciplines. There are claims about disciplinary differences in inquiry (Aulls \& Shore, 2008; Breslyn \& McGinnis, 2012) that may lead learners to conceptualize inquiry differently. Hence, investigating the relationship between inquiry conceptions and epistemic beliefs by considering specific areas of studies would be a contribution to the literature.

4. Furthermore, because of the great variation in the number of participants at different levels of studies, we did not examine differences relative to years of studies. Future studies could include a sufficient number of participants from different levels of studies and examine conceptions of inquiry and their relation to epistemic beliefs. This basically would help to see whether advancement in level of education had a role in the obtained results.

\section{References}

Agresti, A. (2002). Categorical data analysis (2nd ed.). Hoboken, NJ: John Wiley \& Sons.

Anderson, R. D. (2002). Reforming science teaching: What research says about inquiry. Journal of Science Teacher Education, 13(1), 1-12. doi:10.1023/A:1015171124982

Aulls, M. W., \& Shore, B. M. (2008). Inquiry in education: The conceptual foundations for research as a curricular imperative (Vol. 1). New York, NY: Lawrence Erlbaum.

Aypay, A. (2010). Teacher education student's epistemological beliefs and their conceptions about teaching and learning. Procedia - Social and Behavioral Sciences, 2(2), 2599-2604. doi:10.1016/j.sbspro.2010.03.380

Baxter Magolda, M. B. (1992). Knowing and reasoning in college: Gender-related patterns in students' intellectual development. San Francisco, CA: Jossey Bass.

Belenky, M. F., Clinchy, B. M., Goldberger, N. R., \& Tarule, J. M. (1986). Women's ways of knowing. New York, NY: Harper Collins.

Bell, P., \& Linn, M. C. (2002). Beliefs about science: How does science instruction contribute? In B. K. Hofer \& P. R. Pintrich (Eds.), Personal epistemology: The psychology of beliefs about knowledge and knowing (pp. 321-346). Mahwah, NJ: Lawrence Erlbaum.

Bendixen, L. D., \& Hartley, K. (2003). Successful learning with hypermedia: The role of epistemological beliefs and metacognitive awareness. Journal of Educational Computing Research, 28(1), 15-30. doi:10.2190/2Y7C-KRDV-5U01-UJGA

Bendixen, L. D., \& Rule, D. C. (2004). An integrative approach to personal epistemology: A guiding model. Educational Psychologist, 39(1), 69-80. doi:10.1207/ s15326985ep3901_7 
Beyer, B. K. (1971). Inquiry in the social studies classroom: A strategy for teaching. Columbus, OH: Charles E. Merrill.

Boden, C. J. (2005). An exploratory study of the relationship between epistemological beliefs and self-directed learning readiness (Unpublished doctoral dissertation). Kansas State University, Manhattan, KS.

Bråten, I., \& Strømsø, H. I. (2004). Epistemological beliefs and implicit theories of intelligence as predictors of achievement goals. Contemporary Educational Psychology, 29, 371-388. doi:10.1016/j.cedpsych.2003.10.001

Bråten, I., \& Strømsø, H. I. (2005). The relationship between epistemological beliefs, implicit theories of intelligence, and self-regulated learning among Norwegian postsecondary students. British Journal of Educational Psychology, 75(4), 539-565. doi:10.1348/000709905x25067

Breslyn, W., \& McGinnis, J. R. (2012). A comparison of exemplary biology, chemistry, earth science, and physics teachers' conceptions and enactment of inquiry. Science Education, 96(1), 48-77. doi:10.1002/sce.20469

Brickman, P., Gormally, C., Armstrong, N., \& Hallar, B. (2009). Effects of inquirybased learning on students' science literacy skills and confidence. International Journal for the Scholarship of Teaching and Learning, 3(2), 1-22.

Brownlee, J., Purdie, N., \& Boulton-Lewis, G. (2001). Changing epistemological beliefs in pre-service teacher education students. Teaching in Higher Education, 6(2), 247-268. doi:10.1080/13562510120045221

Chan, K.-W. (2007). Hong Kong teacher education students' epistemological beliefs and their relations with conceptions of learning and learning strategies. The Asia-Pacific Education Researcher, 16(2), 199-214.

Chan, K.-W. (2011). Preservice teacher education students' epistemological beliefs and conceptions about learning. Instructional Science, 39(1), 87-108. doi:10.1007/s11251009-9101-1

Chan, K.-W., \& Elliott, R. G. (2004a). Epistemological beliefs across cultures: Critique and analysis of beliefs structure studies. Educational Psychology, 24(2), 123-142. doi:10.1080/0144341032000160100

Chan, K.-W., \& Elliott, R. G. (2004b). Relational analysis of personal epistemology and conceptions about teaching and learning. Teaching and Teacher Education, 2O(8), 817-831. doi:10.1016/j.tate.2004.09.002

Cheng, M. M. H., Chan, K.-W., Tang, S. Y. F., \& Cheng, A. Y. N. (2009). Pre-service teacher education students' epistemological beliefs and their conceptions of teaching. Teaching and Teacher Education, 25(2), 319-327. doi:10.1016/j.tate.2008.09.018

Dahl, T. I., Bals, M., \& Turi, A. L. (2005). Are students' beliefs about knowledge and learning associated with their reported use of learning strategies? British Journal of Educational Psychology, 75(2), 257-273. doi:10.1348/000709905x25049

Duell, O. K., \& Schommer-Aikins, M. (2001). Measures of people's beliefs about knowledge and learning. Educational Psychology Review, 13(4), 419-449. doi:10.1023/a:1011969931594 
DuVall, R. (2001). Inquiry in science: From curiosity to understanding. Primary Voices K-6, 1O(1), 3-9.

Entwistle, N., \& Peterson, E. R. (2004). Conceptions of learning and knowledge in higher education: Relationships with study behaviour and influences of learning environments. International Journal of Educational Research, 41(6), 407-428. doi:10.1016/j.ijer.2005.08.009

Entwistle, N., Skinner, D., Entwistle, D., \& Orr, S. (2000). Conceptions and beliefs about "good teaching": An integration of contrasting research areas. Higher Education Research and Development, 19(1), 5-26. doi:10.1080/07294360050020444

Frank, H., \& Althoen, S. C. (1994). Statistics: Concepts and applications. Cambridge, UK: Cambridge University Press.

Fuselier, L., Bougary, A., \& Malott, M. (2011). From trace evidence to bioinformatics: Putting bryophytes into molecular biology education. Biochemistry and Molecular Biology Education, 39(1), 38-46. doi:10.1002/bmb.20458

Getahun, D. A., Aulls, M., and Saroyan, A. (2014). The nature of undergraduate students' conceptions of inquiry. Electronic Journal of Science Education 18(8), 1-24.

Greco, J. (2000). Putting skeptics in their place: The nature of skeptical arguments and their role in philosophical inquiry. Cambridge, UK: Cambridge University Press

Hammer, D., \& Elby, A. (2002). On the form of a personal epistemology. In B. K. Hofer \& P. R. Pintrich (Eds.), Personal epistemology: The psychology of beliefs about knowledge and knowing (pp. 169-190). New York, NY: Routledge.

Henson, K. T. (1986). Inquiry learning: A new look. Contemporary Education, 57(4), 181-183.

Hofer, B. K. (2000). Dimensionality and disciplinary differences in personal epistemology. Contemporary Educational Psychology, 25(4), 378-405. doi:10.1006/ ceps.1999.1026

Hofer, B. K. (2001). Personal epistemology research: Implications for learning and teaching.EducationalPsychology Review,13(4),353-383.doi:10.1023/a:1011965830686

Hofer, B. K., \& Pintrich, P. R. (1997). The development of epistemological theories: Beliefs about knowledge and knowing and their relation to learning. Review of educational research, 67(1), 88-140. doi:10.3102/00346543067001088

Hurd, D. D. (2008). A microcosm of the biomedical research experience for upperlevel undergraduates. Cell Biology Education, 7(2), 210-219. doi:10.1187/cbe.07-090089

Iqbal, M. Z., \& Chowdhury, S. H. (2007). Using on-campus monitoring wells to enhance student learning in geo-hydrology courses. Journal of Geoscience Education, 55(5), 364-370.

Jehng, J. J., Johnson, S. D., \& Anderson, R. C. (1993). Schooling and students' epistemological beliefs about learning. Contemporary Educational Psychology, 18(1), 23-35. doi:10.1006/ceps.1993.1004 
Kerlinger, F. N. (1986). Foundations of behavioral research (3rd ed.). Chicago, IL: Holt, Rinehart and Winston.

King, P., \& Kitchener, K. S. (1994). Developing reflective judgment: Understanding and promoting intellectual growth and critical thinking in adolescents and adults. San Francisco, CA: Jossey-Bass.

Kuhn, D. (1991). The skills of argument. Cambridge, UK: Cambridge University Press.

Kuzborska, I. (2011). Links between teachers' beliefs and practices and research on reading. Reading in a Foreign Language, 23(1), 102-128.

Leech, N. L., Barrett, K. C., \& Morgan, G. A. (2005). SPSS for intermediate statistics: Use and interpretation (2nd ed.). Mahwah, NJ: Lawrence Erlbaum.

Liu, S.-Y., \& Lederman, N. G. (2007). Exploring prospective teachers' worldviews and conceptions of nature of science. International Journal of Science Education, 29(10), 1281-1307. doi:10.1080/09500690601140019

Liu, S.-Y., \& Tsai, C.-C. (2008). Differences in the scientific epistemological views of undergraduate students. International Journal of Science Education, 3O(8), 1055-1073. doi:10.1080/09500690701338901

Llewellyn, D. J. (2005). Teaching high school science through inquiry: A case study approach. Thousand Oaks, CA: Corwin Press.

Manconi, L., Aulls, M., \& Shore, B. (2008). Teachers' use and understanding of strategy in inquiry instruction. In B. M. Shore, M. W. Aulls, \& M. A. B. Delcourt (Eds.), Inquiry in education: Overcoming barriers to successful implementation (Vol. 2, pp. 247-269). New York, NY: Lawrence Erlbaum.

Martin-Hansen, L. (2002). Defining inquiry: Exploring the many types of inquiry in the science classroom. Science Teacher, 69(2), 34-37.

McNeal, K. S., Miller, H. R., \& Herbert, B. E. (2008). The effect of using inquiry and multiple representations on introductory geology students' conceptual model development of coastal eutrophication. Journal of Geoscience Education, 56(3), 201-211.

Minstrell, J. (2000). Implications for teaching and learning inquiry: A summary. In J. Minstrell \& E. H. v. Zee (Eds.), Inquiring into inquiry learning and teaching in science (pp. 471-496). Washington, DC: American Association for the Advancement of Science.

Muis, K. R. (2004). Epistemic styles and mathematics problem solving: Examining relations in the context of self-regulated learning (Unpublished doctoral dissertation). Simon Fraser University, Burnaby, Canada.

Muis, K. R., Bendixen, L. D., \& Haerle, F. C. (2006). Domain-generality and domainspecificity in personal epistemology research: Philosophical and empirical reflections in the development of a theoretical framework. Educational Psychology Review, 18(1), 3-54. doi:10.1007/s10648-006-9003-6

Muis, K. R., \& Franco, G. M. (2009). Epistemic beliefs: Setting the standards for self-regulated learning. Contemporary Educational Psychology, 34(4), 306-318. doi:10.1016/j.cedpsych.2009.06.005 
National Research Council. (2000). Inquiry and the national science education standards: A guide for teaching and learning. Washington, DC: National Academy Press.

Nugent, G., Kunz, G., Levy, R., Harwood, D., \& Carlson, D. (2008). The impact of a field-based, inquiry-focused model of instruction on preservice teachers' science learning and attitudes. Electronic Journal of Science Education, 12(2), 1-18.

Nussbaum, E. M., Sinatra, G., \& Poliquin, A. (2008). Role of epistemic beliefs and scientific argumentation in science learning. International Journal of Science Education, 30(15), 1977-1999. doi:10.1080/09500690701545919

Otting, H., Zwaal, W., Tempelaar, D., \& Gijselaers, W.(2010). The structural relationship between students' epistemological beliefs and conceptions of teaching and learning. Studies in Higher Education, 35(7), 741-760. doi:10.1080/03075070903383203

Pajares, M. F. (1992). Teachers' beliefs and educational research: Cleaning up a messy construct. Review of Educational Research, 62(3), 307-332. doi:10.3102/00346543062003307

Paulsen, M., \& Feldman, K. (1999). Student motivation and epistemological beliefs. New Directions for Teaching and Learning, 1999(78), 17-25.

Perry, W. G. (1970). Forms of intellectual and ethical development in the college years: A scheme. New York, NY: Holt, Rinehart and Winston.

Phan, H. P. (2008). Multiple regression analysis of epistemological beliefs, learning approaches, and self-regulated learning. Electronic Journal of Research in Educational Psychology, 6(1), 157-184.

Quitadamo, I. J., Faiola, C. L., Johnson, J. E., \& Kurtz, M. J. (2008). Community-based inquiry improves critical thinking in general education biology. Cell Biology Education, 7(3), 327-337. doi:10.1187/cbe.07-11-0097

Ravindran, B., Greene, B., \& Debacker, T. (2005). Predicting preservice teachers' cognitive engagement with goals and epistemological beliefs. The Journal of Educational Research, 98(4), 222-233. doi:10.3200/JOER.98.4.222-233

Roehrig, G., \& Luft, J. (2004). Constraints experienced by beginning secondary science teachers in implementing scientific inquiry lessons. International Journal of Science Education, 26(1), 3-24. doi:10.1080/0950069022000070261

Roy, D., Kustra, E., \& Borin, P.(2003). What is unique about inquiry courses? Retrieved from http://cll.mcmaster.ca/resources/misc/whats_unique_about_inquiry.html

Rye, J. A., \& Rubba, P. A. (2002). Scoring concept maps: An expert map-based scheme weighted for relationships. School Science and Mathematics, 102(1), 33-44. doi:10.1111/j.1949-8594.2002.tb18194.x

Säljö, R. (1979). Learning in the learner's perspective. 1: Some common-sense conceptions (Report No. 76). Göteborg, Sweden: Institute of Education, University of Göteborg.

Schommer,M.(1990).Effectsofbeliefs aboutthenatureofknowledgeoncomprehension. Journal of Educational Psychology, 82(3), 498-504. doi:10.1037//0022-0663.82.3.498 
Schommer, M. (1993). Epistemological development and academic performance among secondary students. Journal of Educational Psychology, 85(3), 406-411. doi:10.1037/0022-0663.85.3.406

Schommer, M. (1998). The influence of age and education on epistemological beliefs. BritishJournalofEducationalPsychology, 68(4),551-562.doi:10.1111/j.2044-8279.1998. tbo1311.x

Schommer, M., Crouse, A., \& Rhodes, N. (1992). Epistemological beliefs and mathematical text comprehension: Believing it is simple does not make it so. Journal of Educational Psychology, 84(4), 435-443. doi:10.1037/0022-0663.84.4.435

Schommer, M., \& Walker, K. (1995). Are epistemological beliefs similar across domains? Journal of Educational Psychology, 87(3), 424-432. doi:10.1037/0022-0663.87.3.424

Schommer-Aikins, M. (2002). An evolving theoretical framework for an epistemological belief system. In B. K. Hofer \& P. R. Pintrich (Eds.), Personalepistemology: The psychology of beliefs about knowledge and knowing (pp. 103-118). New York, NY: Routledge.

Schommer-Aikins, M., \& Easter, M. (2008). Epistemological beliefs' contributions to study strategies of Asian Americans and European Americans. Journal of Educational Psychology, 100(4), 920-929. doi:10.1037/0022-0663.100.4.920

Schraw, G., Bendixen, L. D., \& Dunkle, M. E. (2002). Development and validation of the Epistemic Beliefs Inventory (EBI). In B. K. Hofer \& P. R. Pintrich (Eds.), Personal epistemology: The psychology of beliefs about knowledge and knowing (pp. 261-275). Mahwah, NJ: Lawrence Erlbaum.

Shore, B. M., Aulls, M. W., \& Delcourt, M. A. B. (Eds.). (2008). Inquiry in education: Overcoming barriers to successful implementation (Vol. 2). New York, NY: Lawrence Erlbaum.

Sosu, E. M., \& Gray, D. S. (2012). Investigating change in epistemic beliefs: An evaluation of the impact of student teachers' beliefs on instructional preference and teaching competence. International Journal of Educational Research, 53, 80-92. doi:10.1016/j.ijer.2012.02.002

Stipek, D. J., Givvin, K. B., Salmon, J. M., \& MacGyvers, V. L. (2001). Teachers' beliefs and practices related to mathematics instruction. Teaching and Teacher Education, 17, 213-226.

Strauss, A., \& Corbin, J. (1998). Basics of qualitative research: Procedures and techniques for developing grounded theory. Thousand Oaks, CA: Sage.

Syer, C. A. (2007). Student teachers' understanding of inquiry instruction (Unpublished doctoral dissertation). McGill University, Montréal, Canada.

Wallace, C. S., Tsoi, M. Y., Calkin, J., \& Darley, M. (2003). Learning from inquirybased laboratories in nonmajor biology: An interpretive study of the relationships among inquiry experience, epistemologies, and conceptual growth. Journal of Research in Science Teaching, 4O(10), 986-1024. doi:10.1002/tea.10127

Wong, A. K.-y., Chan, K.-w., \& Lai, P.-y. (2009). Revisiting the relationships of epistemological beliefs and conceptions about teaching and learning of pre-service teachers in Hong Kong. The Asia-Pacific Education Researcher, 18(1), 1-19. 
Yilmaz-Tuzun, O., \& Topcu, M. S. (2008). Relationships among pre-service science teachers' epistemological beliefs, epistemological world views, and self-efficacy beliefs. International Journal of Science Education, 30(1), 65-85.

Zhu, C., Valcke, M., \& Schellens, T. (2008). The relationship between epistemological beliefs, learning conceptions, and approaches to study: A cross-cultural structural model? Asia Pacific Journal of Education, 28(4), 411-423. doi:10.1080/02188790802468823

\section{Contact Information}

Dawit Asrat Getahun

Department of Psychology

College of Education \& Behavioral Sciences

Bahir Dar University

dawit.getahun@mail.mcgill.ca

Dawit Asrat Getahun is an assistant professor in the Department of Psychology, Bahir Dar University, Ethiopia. He has worked as the research and community services co-ordinator of the College of Education and Behavioral Sciences at the university. He is presently working as the director of the institute for pedagogical and educational research at the university. This study is part of his doctoral dissertation at McGill University (Montréal, Canada) under the supervision of the co-authors. His research interests are in the areas of inquiry learning and instruction, teaching and learning conceptions, epistemic beliefs, and, recently, critical thinking among higher education students.

Alenoush Saroyan is a professor and the previous Chair of the Department of Educational and Counselling Psychology at McGill University. Her areas of specialization and research are the pedagogical development of academics, academic leadership, quality assurance, and the reform of postsecondary systems. She serves as a consultant to various international organizations, including The World Bank and the OECD. Her publications include articles, edited books, and book chapters on university professors' conceptions of teaching and on teaching and educational development at the university level.

Mark W. Aulls is a professor emeritus in the Learning Sciences program at McGill University. He was President of the Montréal Reading Association, Member of the Board of Directors of the National Reading Conference, and Team Leader of the Québec Centre for the Study of Learning. Professor Aulls's research interests include: reading fluency, strategies, and comprehension; the study of classroom discourse in elementary, secondary, and university settings; undergraduate students' perceptions of the quality of university instruction; the nature of inquiry learning; and the distinctions between inquiry instruction and non-inquiry instruction in higher education generally and, most recently, in education and STEM subjects. 